\title{
Effect of palm kernel expeller as supplementation on production performance of Jersey cows grazing kikuyu-ryegrass pasture
}

\author{
J.D.V. Van Wyngaard ${ }^{\mathrm{ab},{ }^{*}}$, R. Meeske ${ }^{\mathrm{a}}$, L.J. Erasmus ${ }^{\mathrm{b}}$ \\ ${ }^{a}$ Department of Agriculture, Western Cape, Outeniqua Research Farm, P. O. Box 249, George 6530, \\ South Africa \\ ${ }^{b}$ Department of Animal and Wildlife Sciences, University of Pretoria, Private Bag X20, Hatfield 0028, \\ South Africa
}

\begin{abstract}
*Corresponding author. Tel.: +27 44803 3700; mobile: +27 82336 0626; fax: +27 44874 7730; e-mail address: jdvvanwyngaard@gmail.com or josefvw@elsenburg.com
\end{abstract}

Submitted to Animal Feed Science and Technology in August 2013

Revised and re-submitted in June/July 2014

Revised and re-submitted in October 2014

\begin{abstract}
The aim of the study was to determine the effect of different inclusion levels of palm kernel expeller (PKE) in dairy concentrates for grazing Jersey cows on lactation performance and rumen fermentation patterns. Forty-eight multiparous, Jersey cows, grazing kikuyu-ryegrass during spring, were blocked according to $4 \%$ fat corrected milk, days in milk and lactation number and randomly allocated to three treatments based on PKE level in the concentrate. The PKE inclusion in the control (C), low PKE (LP), and high PKE (HP) treatment concentrates was 0,200 , and $400 \mathrm{~g} / \mathrm{kg}$, respectively, and was fed for a $60 \mathrm{~d}$ period, preceded by a $21 \mathrm{~d}$ adaptation period. The PKE partially substituted some of the maize and soybean in the concentrate. Additionally, eight rumen-fistulated, lactating dairy cows were randomly allocated to the $\mathrm{C}$ and $\mathrm{HP}$ treatment in a two period cross-over design. Cows received $6 \mathrm{~kg}$ (as is) concentrate per day divided over two milkings and strip-grazed pasture as one group.
\end{abstract}


Milk yield and milk fat content did not differ between treatments and were 21.3, 21.3 and $20.7 \mathrm{~kg} / \mathrm{cow} / \mathrm{d}$ and 46.3 , and 46.5 , and $46.6 \mathrm{~g} / \mathrm{kg}$ for the $\mathrm{C}$, LP and HP treatment, respectively. Milk protein, milk urea nitrogen, body weight and body condition score did not differ between cows on all treatments. Total volatile fatty acid, mean ruminal $\mathrm{pH}$, ammonia nitrogen, and in situ pasture dry matter and neutral detergent fibre degradability did not differ between cows on all treatments. The acetic to propionic acid ratio was higher $(\mathrm{P}=0.006)$ for cows receiving treatment HP compared to cows receiving treatment $\mathrm{C}$ (3.40 vs. 3.22). It was concluded that PKE can sustain milk yield and milk fat components at a level of up to 400 $\mathrm{g} / \mathrm{kg}$ of concentrate when fed at $6 \mathrm{~kg} / \mathrm{cow} / \mathrm{d}$ to cows grazing kikuyu-ryegrass pasture. A more practical recommendation might be to limit PKE to $200 \mathrm{~g} / \mathrm{kg}$ of concentrate due to potential palatability problems and a slow rate of intake when fed during milking in the parlour.

Keywords: Byproduct; fibre-based concentrate; NDF; milk production; milk composition; rumen fermentation

Abbreviations: PKE, palm kernel expeller; PKC, palm kernel cake; PKM, palm kernel meal; SEPKC, solvent extracted palm kernel cake; TMR, total mix ration; RPM, rising plate meter; DMI, dry matter intake; FCM, fat corrected milk; C, control treatment; LP, low PKE treatment; HP, high PKE treatment; MUN, milk urea nitrogen; BW, body weight; BCS, body condition score; DM, dry matter; $\mathrm{CP}$, crude protein; ME, metabolisable energy; NDF, neutral detergent fibre; ADF, acid detergent fibre; ADL, acid detergent lignin; EE, ether extract; IVOMD, in vitro organic matter digestibility; OMD, organic matter digestibility; VFA, volatile fatty acid; A:P, acetic to propionic acid ratio; $\mathrm{DM}_{\mathrm{d}}$, dry matter degradability; $\mathrm{NDF}_{\mathrm{d}}$, neutral detergent fibre degradability; NDF $\mathrm{k}_{\mathrm{d}}$, neutral detergent fibre degradability rate 


\section{Introduction}

The nutrient requirements of high-producing dairy cows cannot be satisfied by only grazing high quality pasture (Dixon and Stockdale, 1999). Allen (2000) stated that energy supply is the first limiting factor for increasing productivity of lactating dairy cows. Supplements can overcome the nutrient gap, but at the cost of potentially substituting pasture dry matter intake (DMI). Supplements are also cost sensitive and are affected by the continuous fluctuation of feed ingredient prices. Therefore, improving the efficiency of production and reducing cost of supplemental concentrates for dairy cows are becoming increasingly important both for the smallholder and commercial dairy farmer. High maize and oilcake prices have a substantial impact on the production cost of milk. Maize grain can constitute up to 700 to $800 \mathrm{~g} / \mathrm{kg}$ of a conventional dairy concentrate and soybean oilcake can constitute up to 80 to $120 \mathrm{~g} / \mathrm{kg}$ of the concentrate (Meeske et al., 2009). According to Meeske et al. (2006), concentrates contribute up to $66 \%$ of the total feed cost in pasture dairy grazing systems and, therefore, expensive energy and protein sources are subject to replacement by less expensive by-product feeds. High fibre by-products can contribute to maintaining a normal ruminal $\mathrm{pH}$, enhance pasture digestion and hence result in increased DMI (Bargo et al., 2003). Bradford and Mullins (2012) stated that the replacement of grain with a non-forage fibre source is profitable in some scenarios and often increases DMI.

Palm kernel cake (PKC), also known as palm kernel meal (PKM), is a residue or byproduct from the palm kernel oil extraction process of the African Palm (Elaeis guineensis) seed, representing ca. 50\% of the original kernel (Abdullah and Hutagalung, 1988; Carvalho et al., 2006) and has long been recognised to be a significant ingredient in animal feed formulation (Collingwood, 1958). There is considerable variation in chemical composition of palm kernel by-products depending on the method of fat removal and the proportion of endocarp remaining (Hindle et al., 1995). Two types of PKC are commercially available: 1) 
oil extracted by screw presses, termed palm kernel expeller (PKE; brown colour) or 2) solvent extraction, termed solvent extracted palm kernel cake (SEPKC; white grey colour) (O`Mara et al., 1999). Palm kernel expeller is usually used for animal feeds rather than SEPKC, especially in ruminant diets because of its fibrous nature (Abdullah et al., 1995). According to MAFF (1992), PKE is considered as a medium quality energy feed with a moderate crude protein (CP) content. O`Mara et al. (1999) added that PKE is a moderate quality feed in terms of digestibility for ruminants (organic matter digestibility (OMD) $<710$ $\mathrm{g} / \mathrm{kg}$ ), but high in fibre, coarse and granular, and lowly palatable (Chanjula et al., 2010). Zahari and Alimon (2003) stated that PKE is used as a source of energy and fibre for dairy cattle at inclusion levels of 300 to $500 \mathrm{~g} / \mathrm{kg}$ of the total diet, however Carvalho et al. (2006) stated that PKM is generally included in small amounts $(<100 \mathrm{~g} / \mathrm{kg})$ in dairy concentrates due to its low palatability. Only one study investigating the effect of PKM on performance of dairy cows could be found. In this study, Carvalho et al. (2006) reported no significant treatment effects on DMI, milk yield, or milk composition when PKM was included in a total mix ration (TMR) at different inclusion levels (50,100 and $150 \mathrm{~g} / \mathrm{kg}$ inclusion). However, the milk lactose content tended to increase as PKM inclusion increased $(0.10>\mathrm{P}>0.05)$. This study also reported that feed costs decreased without negative effects on productive responses when PKM was included up to $150 \mathrm{~g} / \mathrm{kg}$ in a TMR. However, the PKM evaluated in the latter study was SEPKC and not PKE.

Further research on the use of PKE in grazing dairy cows is justified as the majority of studies regarding PKE on animal production were performed on goats, beef cattle and water buffalo. Feeding recommendations on inclusion levels cannot be made with confidence, because the number of studies in which fibre-based concentrates replaced starch-based concentrates is limited and half of the studies were conducted in confinement (Bargo et al., 2003). The energy value of a dairy concentrate will decrease when PKE replaces maize and 
this should decrease milk production. The question is to what extent improved pasture digestion will compensate for the lower ME intake on concentrates containing more PKE and less maize.

The objectives of this study were to determine the effect of partially replacing maize with PKE in concentrates for dairy cows on milk production, milk composition, BW, BCS and rumen environment of cows grazing kikuyu-ryegrass pasture during spring.

\section{Materials and methods}

\subsection{Location description}

The study was conducted at the Outeniqua Research Farm (33 $58^{\prime} 38^{\prime \prime} \mathrm{S}$ and $22^{\circ} 25^{\prime} 16^{\prime \prime} \mathrm{E}$; altitude $210 \mathrm{~m}$ above sea level) near George, South Africa. The area has a temperate climate with a long-term (45 years) mean annual precipitation of $732 \mathrm{~mm}$, received throughout the year (ARC-ISCW, 2011). During the study period the total precipitation was $277.4 \mathrm{~mm}$ and the mean daily maximum- and mean daily minimum temperatures were $19.9^{\circ} \mathrm{C}$ and $9.3^{\circ} \mathrm{C}$, respectively. The paddock where the study was conducted consisted of 8.55 ha of permanent irrigated kikuyu (Pennisetum clandestinum) and annual ryegrass (Lolium multiflorum var. italicum) pasture. The soil properties of this paddock are described in detail by Swanepoel et al. (2013). The study was performed from the $12^{\text {th }}$ of August 2011 to the $1^{\text {st }}$ of November 2011 with a $60 \mathrm{~d}$ data collecting period.

\subsection{Pasture performance management}

The pastures were managed as an irrigated pasture under a no-tillage regime, according to the recommended guidelines for kikuyu-ryegrass (Botha, 2003). The pasture consisted predominantly of ryegrass during the study period, since kikuyu is dormant during August and September in the southern Cape region (Botha, 2003). The paddock was divided into 39 strips, with each strip having a length of $150 \mathrm{~m}$ and a width of $15 \mathrm{~m}$. Each strip was top- 
dressed with $42 \mathrm{~kg}$ of $\mathrm{N} / \mathrm{ha}$ after each grazing using limestone ammonium nitrate $(280 \mathrm{~g}$ $\mathrm{N} / \mathrm{kg}$ ). Pasture dry matter (DM) yield per area was estimated by using the rising plate meter (RPM), which was calibrated according to the methods described by Van der Colf (2011). Allocated strip length prior to grazing was determined by the available DM herbage present on the strip above $30 \mathrm{~mm}$, which was calculated using the RPM measurements and seasonal regression equation (Table 1). Cows receiving the different treatments strip-grazed the pasture as one group, which was allocated at $c a .10 \mathrm{~kg} \mathrm{DM} / \mathrm{cow} / \mathrm{d}$. An after-grazing height of $50 \mathrm{~mm}$ was maintained to ensure that the pasture was not over-grazed and that the cows received adequate pasture. This was done by adjusting the allocated kilogram DM pasture per cow using the estimated DM yield per hectare. A 28 d grazing cycle was implemented. Fresh drinking water was available ad libitum. The pasture parameters collected over the period of the study are shown in Table 1 . The mean chemical composition of the kikuyu-ryegrass

Table 1 : Mean ( \pm standard deviation) of the pre- and post-grazing rising plate meter height $(\mathrm{n}=109)$, pasture yield above $30 \mathrm{~mm}$, pasture allowance and pasture intake determined using the seasonal linear regression $(Y=$ $119.94 * H-897.71 ; Y=$ pasture yield and $H=$ rising plate meter height)

\begin{tabular}{lc}
\hline Parameter & Pasture Values \\
\hline Pre-grazing & $24.7 \pm 3.2$ \\
$\mathrm{RPM}^{1}$ height $(1 \mathrm{unit}=5 \mathrm{~mm})$ & $2061 \pm 378$ \\
Pasture yield $(\mathrm{kg} \mathrm{DM} / \mathrm{ha})^{*}$ & $11.1 \pm 1.5$ \\
Pasture allowance $(\mathrm{kg} \mathrm{DM} / \mathrm{cow} / \mathrm{d})$ & \\
& \\
Post-grazing & $10.7 \pm 0.9$ \\
RPM height $(1 \mathrm{unit}=5 \mathrm{~mm})$ & $388 \pm 109$ \\
Pasture yield $(\mathrm{kg} \mathrm{DM} / \mathrm{ha})^{*}$ & $1674 \pm 368$ \\
Pasture removed $(\mathrm{kg} \mathrm{DM} / \mathrm{ha})$ & $9.0 \pm 1.4$ \\
Estimated pasture intake $(\mathrm{kg} \mathrm{DM} / \mathrm{cow} / \mathrm{d})$ & \\
\hline
\end{tabular}

\footnotetext{
${ }^{1}$ RPM-rising plate meter; DM-dry matter.

* Estimated pasture yield above $30 \mathrm{~mm}$ ground level.
} 
Table 2 : The ingredient and mean ( \pm standard deviation) chemical composition of each of the three treatment concentrates $(n=4)$, chemical composition of the palm kernel expeller $(n=4)$ included in the concentrates and the chemical composition of the kikuyu-ryegrass pasture $(n=8)$ at point of grazing in spring

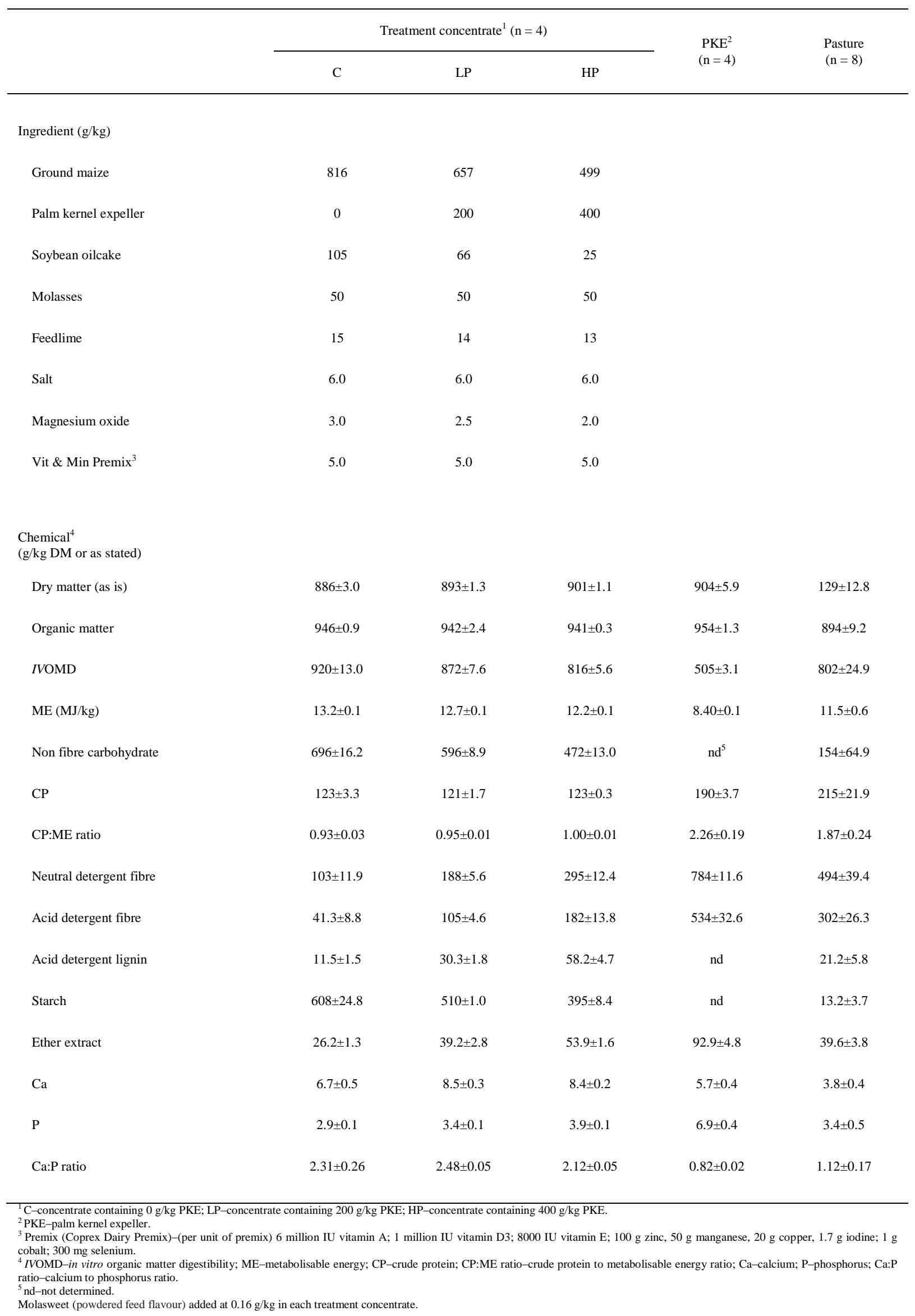


pasture utilised during spring is shown in Table 2.

\subsection{Cows and treatments}

This study consisted of a milk production and rumen fermentation study using intact lactating cows and lactating rumen-fistulated cows, respectively. The two studies were conducted concurrently. Cows from both the studies were milked together, but the milk production data of cows in the rumen fermentation study were excluded from the production study as these cows had to be switched over due to the experimental design.

Cows walked $c a .800 \mathrm{~m}$ before and after each milking as one group. Cows were milked in groups of 20 cows twice a day (05:30 and 15:30) using a 20-point Dairy Master swing over milking machine with weigh-all electronic milk meters (Total Pipeline Industries, 33 Van Riebeeck Street, Heidelberg, South Africa, 6665), and clusters removed manually. Three concentrate substitution rates were formulated as shown in Table 2: 1) control (C; $0 \mathrm{~g} / \mathrm{kg}), 2)$ low PKE (LP; $200 \mathrm{~g} / \mathrm{kg}$ ), or 3) high PKE (HP; $400 \mathrm{~g} / \mathrm{kg}$ ). The PKE replaced part of the maize and soybean oilcake in the concentrate. The $\mathrm{C}$ treatment concentrate can be described as a high starch/low fibre-based concentrate, the LP treatment concentrate as a medium starch/medium fibre-based concentrate and the HP treatment concentrate as a low starch/high fibre-based concentrate, respectively. This is due to the decrease in metabolisable energy (ME), starch, non fibre carbohydrate and in vitro organic matter digestibility (IVOMD), and the increase in neutral detergent fibre (NDF), acid detergent fibre (ADF) and acid detergent lignin (ADL) levels in the order of $\mathrm{C}<\mathrm{LP}<\mathrm{HP}$ concentrate. Concentrates of the different treatments were fed individually to cows in the milking parlour at $6 \mathrm{~kg} / \mathrm{cow}$ (as is) divided over two milkings. Concentrates were balanced to be iso-nitrogenous and were fed in meal form. Molasweet (Nutec Explicit Nutrition, Block G, Hilton Quarry Office Park, 400 Old Howick Road, Hilton, KZN), a powdered feed flavour was added at $0.16 \mathrm{~g} / \mathrm{kg}$ to each of the three treatment concentrates to enhance palatability. 


\subsubsection{Production study}

Forty-eight multiparous, Jersey cows (4\% FCM, 27.2 $\pm 4.1 \mathrm{~kg} / \mathrm{d}$; days in milk, 83.5 \pm 41.3 ; lactation number, $3.9 \pm 1.8$; mean $\pm \mathrm{SD}$ ) were selected based on their $4 \%$ FCM, days in milk and lactation number and randomly allocated to the C, LP and HP treatment concentrates. Milk yield was recorded daily and milk composition was determined fortnightly over a $60 \mathrm{~d}$ period, after a $21 \mathrm{~d}$ adaptation period $(7 \mathrm{~d}$ on the pasture with ad libitum access to PKE followed by $14 \mathrm{~d}$ of feeding allocated treatments in the milking parlour).

\subsubsection{Rumen fermentation study}

Eight lactating, rumen-fistulated cows were randomly allocated to either the $\mathrm{C}$ or the HP treatment in a two period cross-over design. All cows were therefore subjected to the $\mathrm{C}$ and HP treatment concentrates. The rationales for not including the LP treatment are due to practical and financial constraints, limited rumen-fistulated cows were available. Due to individual variation between cows a cross-over experimental design was implemented. Pasture growing season is a major factor to take into account as pasture quality may change over time. A $2 \times 2$ cross-over design takes less time to complete than a $3 \times 3$ cross-over. Cows have previously been fitted with Bar Diamond \#1C rumen cannulae (Bar Diamond Inc, P.O. Box 60, Parma, Idaho, USA). Cows were once-off subjected to a $7 \mathrm{~d}$ adaptation period with ad libitum access to PKE at pasture followed by $20 \mathrm{~d}$ adaptation of feeding the allocated treatment concentrates in the milking parlour before each data collection period. Data were collected over a period of $8 \mathrm{~d}$ for each of the two cross-over periods. Ruminal $\mathrm{pH}, \mathrm{NH}_{3}-\mathrm{N}$, VFA's and in situ pasture DM degradability $\left(\mathrm{DM}_{\mathrm{d}}\right)$, NDF degradability $\left(\mathrm{NDF}_{\mathrm{d}}\right)$ as well as rate of $\mathrm{NDF}_{\mathrm{d}}\left(\mathrm{NDF} \mathrm{k}_{\mathrm{d}}\right)$ were determined. 


\subsection{Experimental measures and sample analyses}

\subsubsection{Pasture and concentrate}

A total of six representative pasture samples $\left(0.098 \mathrm{~m}^{2}\right.$ each $)$ were cut weekly at a stubble height of $30 \mathrm{~mm}$ at point of grazing. Pasture samples required for the in situ nylon bag technique were cut concurrently at a height of $30 \mathrm{~mm}$ given a pasture yield of $>1500 \mathrm{~kg}$ $\mathrm{DM} / \mathrm{ha}$. Samples were dried at $60^{\circ} \mathrm{C}$ for $72 \mathrm{~h}$ in a force-draft oven to determine the DM content (Botha, 2003). The six pasture samples for chemical analyses cut per week were pooled, milled with a SMC Hammer mill to pass a $1 \mathrm{~mm}$ screen, resulting in eight pooled pasture samples, and stored at $-20^{\circ} \mathrm{C}$ pending chemical analyses. Dried samples for the in situ nylon bag study were cut into $5-10 \mathrm{~mm}$ segments. Weekly grab samples of each treatment concentrate were taken and pooled fortnightly, resulting in 12 concentrate samples (four for each treatment) at the end of the study. Dry matter of the concentrate samples was recorded in the exact same way as the pasture samples.

Pasture and concentrate samples of the feed offered were analysed for DM, ash, CP (N determined using LECO Trumac ${ }^{\mathrm{TM}}$ N Determinator, LECO Corporation, Saint Joseph, MI, USA; $\mathrm{CP}=\mathrm{N} \times$ 6.25), calcium $(\mathrm{Ca})$, phosphorus $(\mathrm{P})$, starch and ether extract $(\mathrm{EE})$, according to procedures of the AOAC (2000): method 934.01, 942.05, 968.06, 935.13, 965.17, 996.11 and 920.39, respectively. Neutral detergent fibre (aNDFom) was determined by filter bag technique with added heat stable alpha-amylase (protein enzyme EC 3.2.1.1; 1,4- $\alpha$-D-glucan glucanohydrolase) and anhydrous sodium sulfite and expressed exclusive of residual ash (Robertson and Van Soest, 1981; using the ANKOM $^{2000}$ fibre analyser, method 9). Acid detergent fibre expressed exclusive of residual ash (ADFom) (Goering and Van Soest, 1970; using the $\mathrm{ANKOM}^{2000}$ fibre analyser, method 8), ADL (sa) (Goering and Van Soest, 1970; by solubilization of cellulose with sulphuric acid), IVOMD (Tilley and Terry, 1963; using rumen fluid from a rumen-fistulated Dohne Merino ram, which was fed good quality Lucerne hay) 
and gross energy (MC - 1000 Modular Calorimeter, Operators Manual) were also analysed. Metabolisable energy (MJ/kg DM) was calculated from IVOMD as follows: $\mathrm{ME}=0.84 \mathrm{x}$ gross energy $\mathrm{x}$ OMD for concentrate samples and $\mathrm{ME}=0.81 \mathrm{x}$ gross energy $\mathrm{x}$ OMD for pasture samples (MAFF, 1984). The following formula was used to calculate non fibre carbohydrate: non fibre carbohydrate $=[100-(\mathrm{NDF}+\mathrm{Ash}+\mathrm{CP}+\mathrm{EE})](\mathrm{NRC}, 2001)$.

\subsubsection{Production parameters}

Milk production was recorded at each milking and milk yields were converted to $4 \%$ FCM according to Gaines (1928). Composite, pooled morning and afternoon milk samples were taken fortnightly for each cow. Milk samples were preserved in potassium dichromate.

Milk component (fat, protein and lactose) analysis was done using the Fourier Transform Spectrometer technology by means of the Bentley FTS (Bentley Instruments Inc., Minnesota, USA, 55318). Milk urea N (MUN) analysis was done by means of a ChemSpec 150 (Bentley Instruments Inc., Minnesota, USA, 55318) that utilises a modified Berthelot reaction. Somatic cell count analysis was performed using flow cytometry by means of the Somacount FCM (Bentley Instruments Inc., Minnesota, USA, 55318).

Cows were weighed using a Tru-Test EziWeigh v. 1.0 scale $(0.5 \mathrm{~kg}$ accuracy, Auckland, New Zealand) and body condition scored at the beginning and completion of the study period. The weighing was done after morning milking, to ensure empty udders, and pooled over two consecutive days to compensate for variation between days for each cows' pasture and water intake, urination, and defecation. The scoring system with a one to five scale was used to determine the body condition of the cows (Wildman et al., 1981). Scoring was focused only on appearance and palpation of back and hind quarters and was performed subjectively by the same person to ensure consistency. Concentrate refusals were collected and recorded after each milking. 


\subsubsection{Rumen parameters}

Ruminal $\mathrm{pH}$ was measured using indwelling $\mathrm{pH}-\mathrm{HR} \mathrm{pH} /$ temperature logging systems (TruTrack Data Logger, www.intech.co.nz). The loggers were protected by a custom-made capsule that fitted in the Bar Diamond \#1C rumen cannula. The Omnilog Data Management Program (v. 1.64) was used to calibrate the loggers with buffer solutions of $\mathrm{pH} \mathrm{4,7}$ and 9. The logging systems logged a mean $\mathrm{pH}$ value in $10 \mathrm{~min}$ intervals over a $4 \mathrm{~d}$ period. Data sets were reduced to $30 \mathrm{~min}$ intervals by taking the mean of every three $10 \mathrm{~min}$ intervals. This was done by averaging the $\mathrm{pH}$ reading before, at and after the specified time, followed by calculating the mean over the four days. After the cross-over, the same procedures were followed and the same $\mathrm{pH}$ data logger was allocated to the same cow in order to reduce variation.

Approximately $100 \mathrm{ml}$ of rumen fluid was collected during each sampling interval from each cow using a customised hand drain pump via a $5 \mathrm{~mm}$ diameter hole in the cannula plug. Rumen fluid samples were collected at three time intervals (06:30, 13:30 and 20:30) during a $24 \mathrm{~h}$ cycle. Samples were sealed air tight directly after extraction pending $\mathrm{pH}$ measurement. The $\mathrm{pH}$ of the samples was determined on site directly after extraction using a hand held $\mathrm{pH}$ logger (WTW pH340i pH meter/data logger attached with a WTW Sentix $41 \mathrm{pH}$ electrode). Samples were filtered through four layers of cheesecloth to remove solid particles. Two samples were prepared for each cow: a 5:1 ratio of rumen fluid and $25 \mathrm{ml} / 100 \mathrm{ml} \mathrm{H}_{3} \mathrm{PO}_{3}$ solution (VFA analyses), and a 6:1 ratio of rumen fluid and $50 \mathrm{ml} / 100 \mathrm{ml} \mathrm{H}_{2} \mathrm{SO}_{4}$ solution $\left(\mathrm{NH}_{3}-\mathrm{N}\right.$ analyses). Samples were stored at $-20^{\circ} \mathrm{C}$ pending analyses. Samples were centrifuged for $10 \mathrm{~min}$ at a centrifugal force of $24732 \mathrm{~m} / \mathrm{s}^{2}$ after which the supernatant was removed and filtered through syringe filters with a $0.45 \mu \mathrm{m}$ GHP (hydrophilic polypropylene) membrane. Volatile fatty acids were analysed according to the method ascribed by (Broderick and Kang, 
1980) modified by (Webb, 1994) and rumen $\mathrm{NH}_{3}-\mathrm{N}$ was analysed according to (Broderick and Kang, 1980).

An in situ nylon bag technique was used to estimate $\mathrm{DM}_{\mathrm{d}}, \mathrm{NDF}_{\mathrm{d}}$ and $\mathrm{NDF} \mathrm{k}_{\mathrm{d}}$ of the available kikuyu-ryegrass pasture affected by different PKE inclusions in the concentrate. Dried cut pasture samples were weighed into nylon bags $(10 \times 20 \mathrm{~cm}$ inner size; $53 \mu \mathrm{m}$ pore size; Bar Diamond Inc, P.O. Box 60, Parma, Idaho, USA). A sample size to bag surface area ratio of $12.5 \mathrm{mg} / \mathrm{cm}^{2}$ was obtained by weighing $5 \mathrm{~g}$ DM of sample into each bag. Nylon bags were sealed using a cable tie and placed in an opaque stocking carrier pending incubation, according to the method described by Cruywagen (2006). Nylon bags were inserted into the rumen simultaneously via rumen cannula and incubated in replicates of two for $0,6,18$ and 30 h. After incubation, nylon bags were rinsed under running cold water for two minutes where after it was preserved at $-20^{\circ} \mathrm{C}$. This was done for each time interval removal. All the nylon bags were washed together in a Defy Twinmaid washing machine with cold water for three consecutive 3 min cycles without spinning (gentle function). After each cycle, the water was drained and replaced with clean cold water. Bags were subsequently dried at $55^{\circ} \mathrm{C}$ for 72 h. The zero time point bags were treated in the same manner, excluding incubation. The in situ bag residues were analysed for DM and NDF content similar to the pasture and concentrate sample analyses. The NDF $\mathrm{k}_{\mathrm{d}}$ was calculated using the NDF rate calculator developed by Van Amburgh et al. (2003).

\subsubsection{Statistical analysis}

For the production study data (milk production, milk component analyses, BW, BCS and concentrate refusals) a randomized block design was implemented. Forty eight intact lactating cows were divided into 16 blocks (three cows per block) according to $4 \%$ FCM, days in milk and lactation number. Treatments (C, LP or HP) were randomly allocated to each block. An analysis of variance with the general linear model procedure was used to test 
for significance among treatment means (SAS, 2012). Covariance was not included due to the blocking of cows, which is expected to minimise variation, based on animal factors, between treatments. The model used to analyze the treatment, block and cow effects on milk, BW and concentrate refusal parameters was: $Y_{i j}=\mu+T_{i}+B_{j}+e_{i j}$, where $Y_{i k}=$ dependent variable from production study data of the $\mathrm{i}^{\text {th }}$ treatment group and $\mathrm{j}^{\text {th }}$ block, $\mu=$ the mean of the population, $\mathrm{T}_{\mathrm{i}}=$ effect of the $\mathrm{i}^{\text {th }}$ treatment $(\mathrm{T}=\mathrm{C}, \mathrm{LP}$ or HP$), \mathrm{B}_{\mathrm{j}}=$ effect of blocks of the $\mathrm{j}^{\text {th }}$ $\operatorname{cow}(\mathrm{B}=1,2,3 \ldots 16)$ and $\mathrm{e}_{\mathrm{ij}}=$ random experimental error.

For the rumen fermentation study data (ruminal $\mathrm{pH}, \mathrm{VFA}$ profile, $\mathrm{NH}_{3}-\mathrm{N}, \mathrm{DM}_{\mathrm{d}}, \mathrm{NDF}_{\mathrm{d}}$ and NDF $\mathrm{k}_{\mathrm{d}}$ ) a cross-over design was implemented. Eight rumen-fistulated cows were randomly divided into the $\mathrm{C}$ and HP treatment groups (four cows per treatment). An analysis of variance with the general linear model procedure was used to test for significance among treatment means (SAS, 2012). The model used to analyze the treatment, period and cow effects on rumen fermentation, $\mathrm{pH}$ and degradability parameters was: $Y_{i k}=\mu+T_{i}+P_{k}+e_{i k}$, where $Y_{i k}=$ dependent variable from rumen fermentation study data of the $i^{\text {th }}$ treatment group (C or HP) on the $\mathrm{k}^{\text {th }}$ period (first or second period in cross-over design), $\mu=$ the mean of the population, $\mathrm{T}_{\mathrm{i}}=$ effect of the $\mathrm{i}^{\text {th }}$ treatment, $\mathrm{P}_{\mathrm{k}}=$ effect of the $\mathrm{k}^{\text {th }}$ period, and $\mathrm{e}_{\mathrm{ik}}=$ random experimental error.

Residuals were normally distributed and had homogeneous variances. Means were separated using the Fischer's test; significance and tendencies were declared at $\mathrm{P}<0.05$ and $0.10>\mathrm{P}>0.05$, respectively (Samuels, 1989).

\section{Results}

\subsection{Production parameters}

The mean milk yield, 4\% FCM, milk components (fat, protein, lactose, somatic cell count and MUN), milk fat and protein yield, as well as change in BW and BCS are 
Table 3 : The mean milk yield, $4 \%$ fat corrected milk, milk fat and protein yield, milk components (fat, protein, lactose, somatic cell count and milk urea nitrogen), body weight, body condition score and total daily concentrate refusals of Jersey cows $(\mathrm{n}=16)$ fed $6 \mathrm{~kg}$ (as is) concentrate per day, which included either 0,200 or $400 \mathrm{~g} / \mathrm{kg}$ PKE inclusion, respectively, grazing kikuyu-ryegrass pasture during spring

\begin{tabular}{|c|c|c|c|c|c|}
\hline \multirow{2}{*}{ Parameter } & \multicolumn{3}{|c|}{ Treatment concentrate $^{1}$} & \multirow{2}{*}{ SEM $^{2}$} & \multirow{2}{*}{ P-value } \\
\hline & $\mathrm{C}$ & LP & HP & & \\
\hline \multicolumn{6}{|l|}{ Production (kg/cow/d) } \\
\hline Milk yield & 21.3 & 21.3 & 20.7 & 0.68 & 0.78 \\
\hline $4 \%$ Fat corrected milk & 23.2 & 23.2 & 22.7 & 0.69 & 0.83 \\
\hline Fat yield & 0.98 & 0.98 & 0.96 & 0.033 & 0.89 \\
\hline Protein yield & 0.75 & 0.73 & 0.72 & 0.022 & 0.64 \\
\hline
\end{tabular}

Milk composition $(\mathrm{g} / \mathrm{kg})$

Fat
Protein
Lactose
Milk urea nitrogen $(\mathrm{mg} / \mathrm{dL})$
Somatic cell count $\left(\mathrm{x} 10^{3}\right.$ cells $\left./ \mathrm{mL}\right)$

Body weight (kg)

Before

After

Change

Body condition score (scale 1 to 5 )
46.3

35.4

$47.3^{\mathrm{a}}$

17.7

166

376

412

$+36.5$

2.44

2.59

$+0.16$

Change
Before

After

.


represented in Table 3. The milk yield, 4\% FCM, milk fat and protein content, MUN concentration and milk fat and protein yield were similar between cows on the C, LP and HP treatments with no differences. The milk lactose content was higher for cows on the $\mathrm{C}$ treatment than for cows on the HP treatment $(\mathrm{P}=0.013)$. Palm kernel expeller supplementation had no effect on BW change or BCS change of lactating dairy cows grazing kikuyu-ryegrass pasture. The total daily concentrate refusals did not differ between treatments.

\subsection{Rumen fermentation parameters}

The mean diurnal ruminal $\mathrm{pH}$ fluctuations measured by using the indwelling $\mathrm{pH}$ logging systems are represented in Fig. 1. The mean time (h) spent below a ruminal $\mathrm{pH}$ of $6.2,6.0$ and 5.8 are represented in Table 4, the mean VFA concentrations, rumen $\mathrm{NH}_{3}-\mathrm{N}$

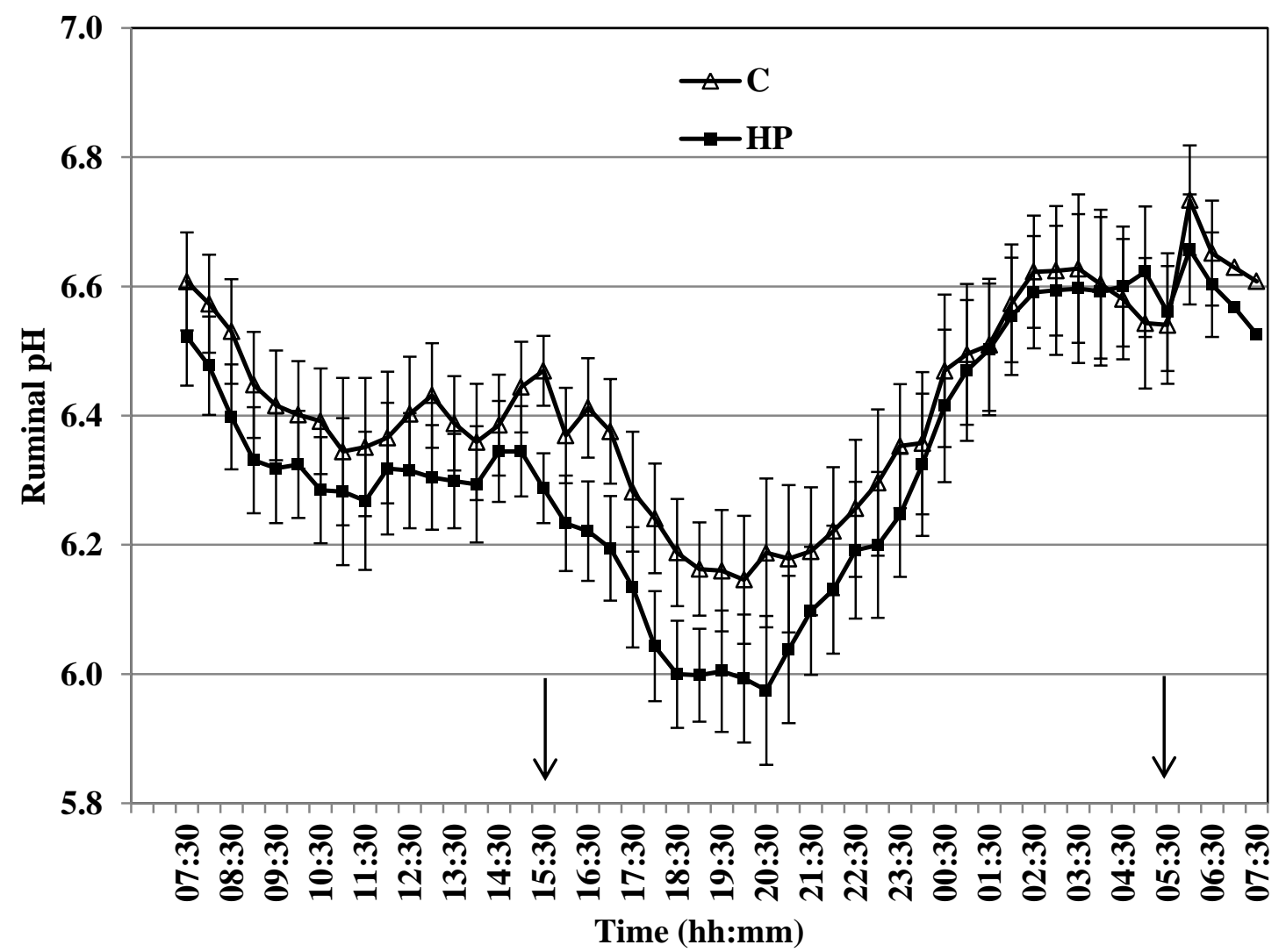

Fig. 1. The mean ruminal diurnal $\mathrm{pH}$ of Jersey cows $(\mathrm{n}=8)$ fed $6 \mathrm{~kg}$ (as is) concentrate per day, which included either 0 (C) or $400 \mathrm{~g} / \mathrm{kg}$ PKE (HP) inclusion, respectively, grazing kikuyu-ryegrass pasture during spring. Arrows indicate when concentrate was fed and error bars indicate SEM 
Table 4 : The mean time (h) spent below a ruminal $\mathrm{pH}$ of $6.2,6.0$ and 5.8 of Jersey cows $(\mathrm{n}=8)$ fed $6 \mathrm{~kg}$ (as is) concentrate per day, which included either 0 (C) or 400 g/kg PKE (HP) inclusion, respectively, grazing kikuyuryegrass pasture during spring

\begin{tabular}{|c|c|c|c|c|}
\hline \multirow{2}{*}{$\mathrm{pH}$} & \multicolumn{2}{|c|}{ Treatment concentrate $^{1}$} & \multirow{2}{*}{$\mathrm{SEM}^{2}$} & \multirow{2}{*}{ P-value } \\
\hline & $\mathrm{C}$ & HP & & \\
\hline$<6.2$ & 6.50 & 9.37 & 2.334 & 0.42 \\
\hline$<6.0$ & 1.88 & 3.44 & 1.605 & 0.52 \\
\hline$<5.8$ & 0.31 & 0.88 & 0.588 & 0.52 \\
\hline
\end{tabular}

${ }^{1}$ Control-concentrate containing 0 g/kg PKE; HP-concentrate containing 400 g/kg PKE; PKE-palm kernel expeller.

${ }^{2}$ SEM-standard error of mean.

Table 5 : Mean volatile fatty acid concentrations, rumen ammonia nitrogen concentrations and handheld $\mathrm{pH}$ measurement in rumen fluid obtained at three time intervals from Jersey cows $(\mathrm{n}=8)$ fed $6 \mathrm{~kg}$ (as is) concentrate per day, which included either 0 (C) or 400 g/kg PKE (HP) inclusion, respectively, grazing kikuyuryegrass pasture during spring

\begin{tabular}{|c|c|c|c|c|}
\hline \multirow{2}{*}{ Rumen Parameter } & \multicolumn{2}{|c|}{ Treatment concentrate $^{1}$} & \multirow{2}{*}{$\mathrm{SEM}^{2}$} & \multirow{2}{*}{ P-value } \\
\hline & $\mathrm{C}$ & HP & & \\
\hline
\end{tabular}

Volatile fatty acids $(\mathrm{mmol} / \mathrm{L})$

$\begin{array}{lcccc}\text { Total } & 121 & 118 & 3.4 & 0.63 \\ \text { Acetic acid } & 76.6 & 75.9 & 2.09 & 0.82 \\ \text { Propionic acid } & 24.2 & 22.8 & 0.60 & 0.14 \\ \text { Acetic to propionic acid ratio (units) } & 3.22 & 3.40 & 0.032 & 0.006 \\ \text { Butyric acid } & 17.3 & 16.5 & 0.67 & 0.43 \\ \text { iso-Butyric acid } & 1.06 & 1.16 & 0.060 & 0.26 \\ \text { Valeric acid } & 1.53 & 1.95 & 0.238 & \\ & & & & 0.39 \\ \text { Ammonia nitrogen (mg/dL) } & 13.8 & 14.6 & 0.59 & \\ \text { Handheld pH } & & & & 0.026\end{array}$

\footnotetext{
${ }^{1} \mathrm{C}$-concentrate containing 0 g/kg PKE; HP-concentrate containing 400 g/kg PKE; PKE-palm kernel expeller.
}

${ }^{2}$ SEM-standard error of mean. 
Table 6 : The in situ dry matter degradability $\left(\mathrm{DM}_{\mathrm{d}}\right)$, neutral detergent fibre degradability $\left(\mathrm{NDF}_{\mathrm{d}}\right)$ and neutral detergent fibre degradability rate $\left(\mathrm{NDF} \mathrm{k}_{\mathrm{d}}\right.$ ) of the available kikuyu-ryegrass pasture during spring at three incubation periods in Jersey cows $(n=8)$ fed concentrate at $6 \mathrm{~kg}$ (as is) per day per cow, which included either 0 (C) or $400 \mathrm{~g} / \mathrm{kg}$ PKE (HP) inclusion

\begin{tabular}{|c|c|c|c|c|c|}
\hline \multirow{2}{*}{ Parameter (coefficient) } & \multirow{2}{*}{$\begin{array}{l}\text { Incubation } \\
\text { period (h) }\end{array}$} & \multicolumn{2}{|c|}{ Treatment concentrate ${ }^{1}$} & \multirow{2}{*}{$\mathrm{SEM}^{2}$} & \multirow{2}{*}{ P-value } \\
\hline & & $\mathrm{C}$ & HP & & \\
\hline \multirow[t]{3}{*}{$\mathrm{DM}_{\mathrm{d}}$} & 6 & 0.53 & 0.55 & 0.029 & 0.65 \\
\hline & 18 & 0.79 & 0.81 & 0.018 & 0.41 \\
\hline & 30 & 0.87 & 0.90 & 0.011 & 0.21 \\
\hline \multirow[t]{3}{*}{$\mathrm{NDF}_{\mathrm{d}}$} & 6 & 0.30 & 0.32 & 0.034 & 0.59 \\
\hline & 18 & 0.65 & 0.68 & 0.028 & 0.49 \\
\hline & 30 & 0.79 & 0.83 & 0.018 & 0.24 \\
\hline \multirow[t]{4}{*}{$\mathrm{NDF} \mathrm{k}_{\mathrm{d}}$ (per hour) } & 6 & 0.08 & 0.08 & 0.007 & 0.88 \\
\hline & 18 & 0.08 & 0.08 & 0.005 & 0.98 \\
\hline & 30 & 0.09 & 0.09 & 0.003 & 0.44 \\
\hline & Mean & 0.08 & 0.08 & 0.004 & 0.91 \\
\hline
\end{tabular}

${ }^{1} \mathrm{C}$-concentrate containing 0 g/kg PKE; HP-concentrate containing 400 g/kg PKE; PKE-palm kernel expeller.

${ }^{2}$ SEM-standard error of mean.

concentrations and handheld $\mathrm{pH}$ treatment effects are represented in Table 5, and the mean in situ $\mathrm{DM}_{\mathrm{d}}, \mathrm{NDF}_{\mathrm{d}}$ and $\mathrm{NDF} \mathrm{k}_{\mathrm{d}}$ of kikuyu-ryegrass pasture are represented in Table 6.

The mean ruminal $\mathrm{pH}$ was not affected by treatment and was 6.42 and 6.33 for the $\mathrm{C}$ and HP treatment, respectively. A difference between treatments in $\mathrm{pH}$ was observed at the 16:30 time interval (6.41 and 6.22 for $\mathrm{C}$ and $\mathrm{HP}$ treatments, respectively; $\mathrm{P}=0.046$ ). This was probably due to cow and logger variability and does not appear to have any significant biological importance, as there were no differences observed between treatments at the remaining time intervals. The extent of ruminal $\mathrm{pH}$ fluctuation was similar for cows receiving 
both treatments and the ruminal $\mathrm{pH}$ decreased steadily in two cyclic $\mathrm{pH}$ drops in the ruminal $\mathrm{pH}$ profile post-feeding concentrate. The highest ruminal $\mathrm{pH}$ for cows receiving both treatments was prior to feeding concentrate $(6.73$ and 6.66 , respectively at $05: 30$, and 6.47 and 6.34, respectively at 15:30) and the lowest ruminal $\mathrm{pH}$ for cows receiving treatment $\mathrm{C}$ and HP was $5 \mathrm{~h}$ post afternoon concentrate feeding (6.15 and 5.97, respectively at 20:30). There were no differences between treatments in the amount of time spend below a $\mathrm{pH}$ of 6.2 , 6.0 or 5.8 .

There were no differences observed in the fatty acid profiles, ruminal $\mathrm{NH}_{3}-\mathrm{N}$ concentrations and handheld ruminal $\mathrm{pH}$ between cows fed the $\mathrm{C}$ and $\mathrm{HP}$ treatments. However, the mean A:P ratio of cows receiving the HP treatment were higher than that of cows fed the $\mathrm{C}$ treatment $(\mathrm{P}=0.006)$.

No differences in $\mathrm{DM}_{\mathrm{d}}, \mathrm{NDF}_{\mathrm{d}}$ or $\mathrm{NDF} \mathrm{k}_{\mathrm{d}}$ were observed at all three incubation times as well as in the mean NDF $k_{d}$ between cows on the C and HP treatments. The high $\mathrm{DM}_{d}$ coefficients obtained at the $30 \mathrm{~h}$ incubation period for cows on the $\mathrm{C}(0.87)$ and HP $(0.90)$ treatments corresponds to the high IVOMD value ( $802 \mathrm{~g} / \mathrm{kg}$; Table 2) obtained for the grazed kikuyu-ryegrass pasture.

\section{Discussion}

\subsection{Pasture and concentrate}

Correct pasture allocation is of immense importance as under-utilisation of pasture will affect pasture quality and over-utilisation of pasture impedes pasture regrowth (Stockdale, 2000). This ensures optimal pasture regrowth and quality (Stockdale, 2000) as well as an indication that cows had sufficient amount of pasture available. The pasture nutrient composition is similar to that reported by Botha et al. (2008). The pasture utilised during this study can be categorised as a high quality, temperate species pasture according to the 
requirements set by Clark and Kanneganti (1998), i.e. NDF of $400-500 \mathrm{~g} / \mathrm{kg}$ and CP of 180 $-250 \mathrm{~g} / \mathrm{kg}$. The chemical composition of PKE in this study is in agreement with the findings of Alimon (2005), except for the higher Ca and EE value and lower ME value observed in this study. The EE value is similar to the findings of Chanjula et al. (2010), however the Ca and $\mathrm{ME}$ values cannot be compared to previous findings. The quality of PKE varies substantially.

\subsection{Production parameters}

\subsubsection{Milk yield}

Milk yield remained unchanged across treatments and is in agreement with previous grazing studies comparing fibre-based to starch-based concentrates (Delahoy et al., 2003; Gehman et al., 2006; Meeske et al., 2009). A review by Bargo et al. (2003) reported that the overall milk production reduced slightly $(-0.46 \mathrm{~kg} / \mathrm{d})$ when starch-based concentrates were replaced by fibre-based concentrates fed to grazing dairy cows, however the milk response ranged from -2.6 to $1.3 \mathrm{~kg} / \mathrm{d}$. The results of the current study are difficult to compare with previous published studies, because no studies could be found where the effect of PKE supplementation was tested on the milk production of grazing dairy cows, even with PKE being a common raw material component in formulated dairy diets. However, the milk yield and 4\% FCM of the current study are in agreement with the results obtained by Carvalho et al. (2006).

The optimum starch content in TMR diets fed to high producing dairy cows is not well defined, but a starch content of $240-260 \mathrm{~g} / \mathrm{kg}$ has been suggested (Staples, 2007). In a survey conducted by Kaiser and Shaver (2006) starch contents varied from $250-300 \mathrm{~g} / \mathrm{kg}$ of dietary DM. Recently, high maize prices have forced nutritionists to partly replace maize with highly digestible non-forage fibre sources such as citrus pulp, soyhulls, maize gluten and distiller's grains. It was concluded that maize can be replaced with by-product feeds resulting 
in low starch diets $(160-210 \mathrm{~g} / \mathrm{kg})$ without adverse effects on ruminal fermentation and lactational performance (Shaver, 2008). Our results support this concept, although this was a pasture-based study. The starch content of the C concentrate was $608 \mathrm{~g} / \mathrm{kg}$ compared to 395 $\mathrm{g} / \mathrm{kg}$ in the HP concentrate. Assuming a pasture DMI of $9.0 \mathrm{~kg}$ and starch content of $13 \mathrm{~g} / \mathrm{kg}$ this would result in a total dietary starch content of $236 \mathrm{~g} / \mathrm{kg}$ and $158 \mathrm{~g} / \mathrm{kg}$, respectively for the $\mathrm{C}$ and $\mathrm{HP}$ treatment concentrates.

As PKE inclusion in the concentrate increased, the maize inclusion decreased. This resulted in a lower ME content in the concentrate as the PKE inclusion increased (Table 2). Even at the lower energy content of the HP concentrate (12.2 MJ ME/kg DM) and an estimated pasture DMI of $9.0 \mathrm{~kg}$ and energy content of $11.5 \mathrm{MJ} \mathrm{ME} / \mathrm{kg} \mathrm{DM}$, the energy requirement of $162 \mathrm{MJ}$ ME would have been satisfied (NRC, 2001). Feeding the higher energy $\mathrm{C}$ concentrate, therefore, exceeded the energy requirement for cows producing $22 \mathrm{~kg}$ milk/d (NRC, 2001). It could be speculated that cows receiving the lower energy content concentrates (LP and HP treatments) had a higher pasture DMI compared to the cows receiving the $\mathrm{C}$ concentrate. This is due to compensate for the lower energy content in the LP and HP concentrates compared to the $\mathrm{C}$ concentrate. Individual pasture intake measurement was, however, needed to confirm this statement. According to Gehman et al. (2006), increased DMI is one of the advantages that fibre-based concentrates have over starch-based concentrates. The review by Bargo et al. (2003) showed that fibre-based concentrates marginally increased DMI by $0.13 \mathrm{~kg} / \mathrm{d}$ (DMI response range: -0.7 to $1.4 \mathrm{~kg} / \mathrm{d}$ ). This was not the case in the current study, where in situ pasture $\mathrm{DM}_{\mathrm{d}}$ and $\mathrm{NDF}_{\mathrm{d}}$ remained unchanged between treatments. Therefore the increased pasture DMI hypothesis should be interpreted with caution. 


\subsubsection{Milk composition}

The milk fat and milk protein results of the current study concur to the results obtained by (Khalili and Sairanen, 2000) and (Carvalho et al., 2006). A review by Bargo et al. (2003) reported that milk protein content was reduced by -0.06 percentage units with fibre-based concentrates compared with starch-based concentrates, with a milk protein response range from -0.21 to 0.05 percentage units. Khalili and Sairanen (2000) reported a higher milk lactose yield for cows supplemented with barley (starch-based) than for cows supplemented with oats, wheat bran and beet pulp (fibre-based), however this could possibly be attributable to increased milk yield, with no alteration in milk lactose percentage. Carvalho et al. (2006) found a tendency for SEPKC inclusion in a TMR to increase lactose contents in milk $(0.10>\mathrm{P}>0.05)$. The concentration of lactose and minerals in milk do not respond predictably to adjustments in the diet (Sutton, 1989). Therefore, the difference in milk lactose content between cows on treatments in our study is perhaps biologically not significant.

Kohn (2007) recommended MUN concentrations between 8 to $12 \mathrm{mg} / \mathrm{dL}$ under typical TMR production conditions. The MUN concentrations in the current study are well above this range. It is generally accepted that MUN ranges for fertilised pasture-based dairy systems are higher than that of cows on TMR systems. This is supported by a summary of MUN values of previous pasture-based studies where cows were supplemented with starch- or fibre-based concentrates: $20.1 \mathrm{mg} / \mathrm{dL}$ with a range of 9.9 to $40.0 \mathrm{mg} / \mathrm{dL}$ (Khalili and Sairanen, 2000; Delahoy et al., 2003; Gehman et al., 2006; Meeske et al., 2009; Lingnau, 2011). The MUN concentrations of the current study indicates that dietary protein was not limiting, but rather fed in excess to some extent, but still within an acceptable range for pasture-based systems. 


\subsubsection{Body weight and condition}

The BW and BCS results of this study are similar to that found by (Sayers et al., 2003) and (Meeske et al., 2009). Bargo et al. (2002a) stated that BW is not subject to change in such a short study period as would comprise a feeding study. It can be postulated that cows did not lose BW or BCS at the expense of maintaining milk yield in the LP and HP treatment groups, therefore the allocated pasture and concentrate provided sufficient energy to sustain milk yield.

\subsubsection{Concentrate refusals}

There are two potential reasons for the refusals of the concentrates. Firstly, concentrates were fed in a meal form in the current study where the cows are normally accustomed to pelleted concentrates. Secondly, the low palatability of PKE could also have contributed to the concentrate refusals of the LP and HP treatment groups. It can be suggested that a longer adaptation period would have overcome the concentrate refusals or the time spent in the milking parlour could be increased, but this, however, is not a practical option in large herds.

\subsection{Rumen fermentation parameters}

\subsubsection{Ruminal pH profile}

The ruminal $\mathrm{pH}$ fluctuation is in agreement with Bargo et al. (2002b) who reported that ruminal $\mathrm{pH}$ is the highest pre-concentrate feeding and lowest post-concentrate feeding. None of the treatment concentrates fed in the current study resulted in cows suffering from acute ruminal acidosis or subacute ruminal acidosis, which are defined by ruminal $\mathrm{pH}<5$ and $\mathrm{pH}<5.6$, respectively, based on the mean and minimum ruminal $\mathrm{pH}$ values (Owens et al., 1996). The mean ruminal $\mathrm{pH}$ of each treatment was well within the range of 6.0 to 6.9 that stimulates optimal ruminal fibre digestion (Kolver et al., 1998). Beauchemin and Rode (1999) stated that a prolonged low ruminal $\mathrm{pH}$ is needed to decrease ruminal fibre digestion. The ruminal $\mathrm{pH}$ of cows on the $\mathrm{C}$ and $\mathrm{HP}$ treatments was below the $\mathrm{pH}$ of 5.8 for less than an 
hour, which is well within the threshold of 475 min below a $\mathrm{pH}$ of 5.8 that is an indicator of subacute ruminal acidosis (AlZahal et al., 2007). This indicates that the combination of the pasture and treatment concentrates provided sufficient buffering capacity to overcome perpetual low $\mathrm{pH}$ values.

Physical effective NDF is strongly associated with milk fat yield and ruminal $\mathrm{pH}$, as was demonstrated by Zebeli et al. (2008). An increase in milk fat content was expected for cows fed the LP and HP treatments due to the high NDF levels of these concentrates, 188 and $295 \mathrm{~g} / \mathrm{kg}$ DM, respectively. The NDF content of non-forage fibre sources, such as PKE, have a small mean particle size, low lignin content and a high fibre digestibility, therefore resulting in a low physical effective NDF (peNDF) content (Bradford and Mullins, 2012). Results, therefore suggest that the similarity obtained in milk fat content between cows receiving the $\mathrm{C}$ and HP treatments, are due to a lack of peNDF content in the PKE included in the concentrates and due to the similar relatively high ruminal $\mathrm{pH}$ values for the three treatments.

The $\mathrm{pH}$ values differed substantially at the specified time intervals between the two $\mathrm{pH}$ measuring systems (indwelling and manual). Colman et al. (2010) stated that $\mathrm{pH}$ varies considerably at different locations in the rumen and during the day. Regardless of this, ruminal $\mathrm{pH}$ was not affected by treatment in either one of the $\mathrm{pH}$ measuring systems.

\subsubsection{Ruminal volatile fatty acid profile}

Sayers et al. (2003) found that supplementation had no effect on total VFA concentration of cows grazing ryegrass pasture when starch-based concentrates were replaced by fibre-based concentrates, regardless of ruminal $\mathrm{pH}$ reductions (Carruthers and Neil, 1997). This is supported by Seymour et al. (2005) who found that ruminal $\mathrm{pH}$ is negatively related to total VFA concentration in rumen fluid. This is in agreement with the total VFA results obtained in the current study. The mean total VFA concentration obtained from cows on both treatments is very similar to the mean total VFA concentration of $120.9 \mathrm{mmol} / \mathrm{L}$ (range: 90.3 
to $151.4 \mathrm{mmol} / \mathrm{L}$ ) compiled by Bargo et al. (2003) from grazing studies. Khalili and Sairanen (2000) reported no change in the three main VFA's which is in agreement with the results of the current study. Milk yield is positively correlated with rumen concentrations of butyric acid followed by propionic acid (Seymour et al., 2005). Accordingly, the milk yield results of the current study coincide with the butyric and propionic acid results. Abdullah and Hutagalung (1988) reported elevated iso-acids when Draughtmaster cattle were fed with a PKC-based diet ad libitum for $185 \mathrm{~d}$. This could be advantageous to the cows as Gorosito et al. (1985) reported that valeric acid and iso-acids improved cellulose digestion in an in vitro study. Unfortunately, no iso-acid or valeric acid differences where observed between cows on the $\mathrm{C}$ and HP treatments which could be attributable to the restricted PKE intake. The A:P ratio found in the ruminal VFA profile plays an important role in establishing the milk fat value as supported by Seymour et al. (2005) who found a positive correlation between A:P ratio and milk fat. On the contrary, milk fat content did not increase for cows on the HP treatment irrespective of an increased A:P ratio. This could be due to a deficiency in peNDF. However, the A:P ratio of all cows on treatments were higher than the value of $2: 1$ that was suggested as a threshold for milk fat depression (Erdman, 1988).

\subsubsection{Ruminal ammonia nitrogen profile}

Satter and Slyter (1974) reported that the minimum ruminal $\mathrm{NH}_{3}-\mathrm{N}$ concentration for maximum microbial protein synthesis is $5 \mathrm{mg} / \mathrm{dL}$. The values observed in the current study were well above this range and suggest that none of the cows receiving the treatment concentrates were deficient in protein. This also indicates that microbial growth was not restricted and thus no reductions in ruminal fibre degradation are expected. The mean ruminal $\mathrm{NH}_{3}-\mathrm{N}$ concentration obtained from cows on both treatments is similar to the mean ruminal $\mathrm{NH}_{3}-\mathrm{N}$ concentration of $18.3 \mathrm{mg} / \mathrm{dL}$ (range: 8.7 to $32.2 \mathrm{mg} / \mathrm{dL}$ ) compiled by Bargo et al. (2003) from grazing studies. 


\subsubsection{Ruminal pasture degradation}

The high $\mathrm{DM}_{\mathrm{d}}$ and $\mathrm{NDF}_{\mathrm{d}}$ coefficients were expected, due to the high quality of the pasture in the current study. Beauchemin (1991) found that an increase in fibre concentration of the diet resulted in an increase in microbial digestion of forage in sacco. However, the results in the current study are in agreement with the findings of Sayers et al. (2003), who found no effect on in situ ruminal digestion of ryegrass. This could be attributed to the fact that there were no differences in mean ruminal $\mathrm{pH}$ between cows on the $\mathrm{C}$ and $\mathrm{HP}$ treatments. This is supported by Beauchemin (1991) who reported that the enhancement of forage digestion may be related to increased ruminal $\mathrm{pH}$ which in return promotes cellulolytic micro-organisms to thrive. Results suggest that the higher NDF level of the HP concentrate did not affect the cellulolytic micro-organism activity in the rumen possibly due to a lack in peNDF.

\section{Conclusions}

Inclusion of PKE up to $400 \mathrm{~g} / \mathrm{kg}$ in the concentrate of grazing dairy cows did not affect milk production, milk fat content, milk protein content or BW and BCS change. Rumen fermentation pattern was not affected by treatment apart from an increased A:P ratio when comparing the $\mathrm{C}$ diet to the HP diet. A more practical recommendation might be to include PKE up to $200 \mathrm{~g} / \mathrm{kg}$ in dairy concentrates due to potential palatability problems and increased feeding time in the milking parlour.

\section{Acknowledgements}

The authors wish to express their sincere gratitude to the Western Cape Agricultural Research Trust, Research and Technology Development Services of the Department of Agriculture Western Cape and to the Department of Animal and Wildlife Sciences at the 
University of Pretoria for providing the funding and infrastructure. The milking team and farm aids at the Outeniqua Research Farm need special reference for their work ethics while executing the trial.

\section{References}

Abdullah, N., Hanita, H., Ho, Y.W., Kudo, H., Julaludin, S., Ivan, M., 1995. The effects of bentonite on rumen protozoal population and rumen fluid characteristics of sheep fed palm kernel cake. Asian-Aust. J. Anim. Sci. 8, 249-254.

Abdullah, N., Hutagalung, R.I., 1988. Rumen fermentation, urease activity and performance of cattle given palm kernel cake-based diet. Anim. Feed Sci. Tech. 20, 79-86.

Alimon, A.R., 2005. The nutritive value of palm kernel cake for animal feed. Palm Oil Developments, vol. 40. Malaysian Palm Oil Board, Kuala Lumpur, Malaysia, pp. 12-14.

Allen, M.S., 2000. Effects of diet on short-term regulation of feed intake by lactating dairy cattle. J. Dairy Sci. 83, 1598-1624.

AlZahal, O., Kebreab, E., France, J., McBride, B.W., 2007. A mathematical approach to predicting biological values from ruminal pH measurements. J. Dairy Sci. 90, 3777-3785.

AOAC International, 2000. Official Methods of Analysis, 17th ed. Association of Official Analytical Chemists, Gaithersburg, MD.

ARC-ISCW, 2011. Agro-Climatology database. The Agricultural Research Council's Institute for Soil Climate and Water, Pretoria, South Africa.

Bargo, F., Muller, L.D., Delahoy, J.E., Cassidy, T.W., 2002a. Milk response to concentrate supplementation of high producing dairy cows grazing at two pasture allowances. J. Dairy Sci. $85,1777-1792$.

Bargo, F., Muller, L.D., Kolver, E.S., Delahoy, J.E., 2003. Invited review: Production and digestion of supplemented dairy cows on pasture. J. Dairy Sci. 86, 1-42. 
Bargo, F., Muller, L.D., Varga, G.A., Delahoy, J.E.,Cassidy, T.W., 2002b. Ruminal digestion and fermentation of high producing dairy cows with three different feeding systems combining pasture and total mixed rations. J. Dairy Sci. 85, 2964-2973.

Beauchemin, K.A., 1991. Ingestion and mastication of feed by dairy cattle. Vet. Clin. North Am. Food Anim. Pract. 7(2), 439-463.

Beauchemin, K.A., Rode, L.M., 1999. Effects of grain source and enzyme additive on site and extent of nutrient digestion in dairy cows. J. Dairy Sci. 82, 378-390.

Botha, P.R., 2003. Die produksiepotensiaal van oorgesaaide kikoejoeweiding in die gematigde kusgebied van die Suid-Kaap. In: Doctoral dissertation. University of the FreeState, Bloemfontein, South Africa.

Botha, P.R., Meeske, R., Snyman, H.A., 2008. Kikuyu over-sown with ryegrass and clover(i): Dry matter production, botanical composition and nutritional value. Afr. J. Range Forage Sci. 25(3), 93-101.

Bradford, B.J., Mullins, C.R., 2012. Invited review: Strategies for promoting productivity and health of dairy cattle by feeding nonforage fiber sources. J. Dairy Sci. 95, 4735-4746.

Broderick, G.A., Kang, J.H., 1980. Automated simultaneous determination of ammonia and total amino acids in ruminal fluid and in vitro media. J. Dairy Sci. 63, 64-75.

Carruthers, V.R., Neil, P.G., 1997. Milk production and ruminal metabolites from cows offered two pasture diets supplemented with non-structural carbohydrate. N.Z. J. Agric. Res. 40, 513-521.

Carvalho, L.P.F., Cabritta, A.R.J., Dewhurst, R.J., Vicente, T.E.J., Lopes, Z.M.C., Fonseca, A.J.M., 2006. Evaluation of palm kernel meal and corn distillers grains in corn silage-based diets for lactating dairy cows. J. Dairy Sci. 89, 2705-2715.

Chanjula, P., Mesang, A. \& Pongprayoon, S., 2010. Effects of dietery inclusion of palm kernel cake on nutrient utilization, rumen fermentation characteristics and microbial 
populations of goats fed Paspalum plicatulum hay-based diet. Songklanakarin J. Sci. Technol. 32(6), 527-536.

Clark, D.A., Kanneganti, V.R., 1998. Grazing management systems for grazing cattle. In: Cherney, J.H., Cherney, D.J.R. (Eds.), Grass for dairy cattle. CAB International, Oxon, UK, pp. 331 .

Collingwood, J.G., 1958. Palm kernel meal. In: Processed Plant Protein Foodstuffs. Academic Press Inc., New York, pp. 677-701.

Colman, E., Fokkink, W.B., Craninx, M., Newbold, J.R., De Baets, B., Fievez, V., 2010. Effect of induction of subacute ruminal acidosis on milk fat profile and rumen parameters. J. Dairy Sci. 93, 4759-4773.

Cruywagen, C.W., 2006. Technical note: A method to facilitate the retrieval of polyester bags used in in sacco trials in ruminants. J. Dairy Sci. 89, 1028-1030.

Delahoy, J.E., Muller, L.D., Bargo, F., Cassidy, T.W., Holden, L.A., 2003. Supplemental carbohydrate sources for lactating dairy cows on pasture. J. Dairy Sci. 86, 906-915.

Dixon, R.M., Stockdale, C.R., 1999. Associative effects between forages and grains: Consequences for feed utilization. Aust. J. Agric. Res. 50, 757-773.

Erdman, R.A., 1988. Dietary buffering requirements of the lactating dairy cow: A review. J. Dairy Sci. 71, 3246-3266.

Gaines, W.L., 1928. The energy basis of measuring milk yield in dairy cows. University of Illinois, Agric. Exp. Station, Bulletin 308.

Gehman, A.M., Bertrand, J.A., Jenkins, T.C., Pinkerton, B.W., 2006. The effect of carbohydrate source on nitrogen capture in dairy cows on pasture. J. Dairy Sci. 89, 26592667.

Goering, H.K., Van Soest, P.J., 1970. Forage Fiber Analysis (apparatus, reagents, procedures and some applications). Agric. Handbook no. 379, ARS-USDA, Washington, D.C. 
Gorosito, A.R., Russell, J.B., Van Soest, P.J., 1985. Effect of carbon-4 and carbon-5 volatile fatty acids on digestion of plant cell wall in vitro. J. Dairy Sci. 68, 840-847.

Hindle, V.A., Steg, A., Van Vuuren, A.M., Vroons-de Bruin, J., 1995. Rumen degradation and post-ruminal digestion of palm kernel by-products in dairy cows. Anim. Feed Sci. Tech. 51, 103-121.

Kaiser, R., Shaver, R., 2006. Benchmarking high producing herds. In Proc. Western Canadian Dairy Seminar, Red Deer, Alberta, Canada. University of Alberta, Edmonton, Alberta, Canada, pp. 179-190.

Khalili, H., Sairanen, A., 2000. Effect of concentrate type on rumen fermentation and milk productions of cows at pasture. Anim. Feed Sci. Tech. 84, 199-212.

Kohn, R., 2007. Use of milk or blood urea nitrogen to identify feed management inefficiencies and estimate nitrogen excretion by dairy cattle and other animals. Florida Ruminant Nutrition Symposium, Gainesville, FL. University of Florida, Gainesville.

Kolver, E.S., Muller, L.D., Barry, M.C., Penno, J.W., 1998. Evaluation and application of the Cornell Net Carbohydrate and Protein System for dairy cows fed diets based on pasture. J. Dairy Sci. 77, 813-824.

Lingnau, W.A.L., 2011. Substitution of maize with high fibre by-products in concentrates supplemented to dairy cows grazing kikuyu/ryegrass pasture during spring. In: Master's thesis. University of Stellenbosch, Stellenbosch, South Africa.

Meeske, R., Cronje, P.C., Van der Merwe, G.D., 2009. High fibre concentrates for Jersey cows grazing kikuyu/ryegrass pasture. In Proc. Annual Information Day at Outeniqua Research Farm. 6 October 2009, pp. 40-42.

Meeske, R., Rothauge, A., Van der Merwe, G.D., Greyling, J.F., 2006. The effect of concentrate supplementation on the productivity of grazing Jersey cows on a pasture based system. S. Afr. J. Anim. Sci. 36, 105-110. 
Meijs, J.A.C., 1986. Concentrate supplementation of grazing dairy cows. 2. Effect of concentrate composition on herbage intake and milk production. Grass Forage Sci. 41, $229-235$.

MAFF, 1984. Energy allowances and feeding systems for ruminants. Ministry of Agriculture, Fisheries and Food, London, HMSO.

MAFF, 1992. UK Tables of Feed Composition and Nutritive Value for Ruminants. In: Feed Composition, 2nd ed. Chalcombe Publications, Nr. Canterbury, UK.

NRC, 2001. Nutrient Requirements of Dairy Cattle: Seventh revised edition. Subcommittee on Dairy Cattle Nutrition, Committee on Animal Nutrition and Board on Agriculture and Natural Resources. National Academy Press, Washington, DC.

O’Mara, F.P., Mulligan, F.J., Cronin, E.J., Rath, M., Caffrey, P.J., 1999. The nutritive value of palm kernel meal measured in vivo and using rumen fluid and enzymatic techniques. Livestock Prod. Sci. 60, 305-316.

Owens, F., Secrist, D., Hill, J., Gill, D., 1996. A new look at acidosis. In Proc. Southwest Nutrition Conf., Hoenix, AZ, pp. 1-16.

Robertson, J.B., van Soest, P.J., 1981. The Detergent System of Analysis and Its Application to Human Foods. In: James, W.P.T., Theander, O. (Eds.), Basic and clinical nutrition vol 3. The analysis of dietary fibre in food. Dekker, NY, pp. 158-276.

Samuels, M.L., 1989. Statistics for the life sciences. Collier MacMillan Publishers, London.

Satter, L.D., Slyter, L.L., 1974. Effect of ammonia concentration on rumen microbial protein production in vitro. Br. J. Nutr. 32, 199-208.

Sayers, H.J., Mayne, C.S., Bartram, C.G., 2003. The effect of level and type of supplement offered to grazing dairy cows on herbage intake, animal performance and rumen fermentation characteristics. Anim. Sci. 76(3), 439-454. 
Seymour, W.M., Campbell, D.R., Johnson, Z.B., 2005. Relationship between rumen volatile fatty acid concentrations and milk production in dairy cows: a literature review. Anim. Feed Sci. Tech. 119, 155-169.

Shaver, R.D., 2008. Coping with high corn prices: low starch diets and lactation performance by dairy cows. In Proc. 6th Mid-Atlantic Nutr. Conf. Timonium, MD, pp. 128-133.

Staples, C.R., 2007. Feeding dairy cows when corn prices are high. In Proc. 44th Florida Dairy Production Conference. Gainesville, FL. University of Florida Extensions, Gainsville, pp. 7-22.

Statistical Analysis Systems Institute, 2012. SAS User`s Guide: Statistics Version 9.2. SAS Institute Inc., Cary, North Carolina, USA.

Stockdale, C.R., 2000. Levels of pasture substitution when concentrates are fed to grazing dairy cows in northern Victoria. Aust. J. Exp. Agric. 40, 913-921.

Sutton, J.D., 1989. Altering milk composition by feeding. J. Dairy Sci. 72, 2801-2814.

Swanepoel, P.A., Botha, P.R., Du Preez, C.C. Snyman, H.A., 2013. Physical quality of a podzolic soil following 19 years of irrigated minimum-till kikuyu-ryegrass pasture. Soil Till. Res. 133, 10-15.

Tilley, J.M., Terry, R.A., 1963. A two-stage technique for the in vitro digestion of forage crops. J. Br. Grassl. Soc. 18, 104-111.

Van Amburgh, M. E., Van Soest, P. J., Robertson, J. B., Knaus, W. F., 2003. Corn silage neutral detergent fiber: Refining a mathematical approach for in vitro rates of digestion. Proc. Cornell Nutr. Conf. Department of Animal Science, Cornell University, Ithaca, NY, pp. 99-108.

Van der Colf, J., 2011. The production potential of Kikuyu (Pennisetum clandestium) pastures over-sown with Ryegrass (Lolium spp.). In: Master's thesis. University of Pretoria, Pretoria, South Africa. 
Webb, E.C., 1994. Synthesis of long chain fatty acids in ruminants and their effects on meat quality. In: Doctoral dissertation. University of Pretoria, Pretoria, South Africa. Chapter 3, pp. 58-59.

Wildman, E.E., Jones, G.M., Wagner, P.E., Boman, R.L., Troutt, H.F., Jr., Lesch, T.N., 1982. A dairy cow body condition scoring system and its relationship to selected production characteristics. J. Dairy Sci. 65, 495-501.

Zahari, M.W., Alimon, A.R., 2003. Use of palm kernel cake and oil palm by-products in compound feed. Palm oil developments 40. Malaysian Palm Oil Board, pp. 5-9.

Zebeli, Q., Dijkstra, J., Tafaj, M., Steingass, H., Ametaj, B.N., Drochner, W., 2008. Modeling the adequacy of dietary fiber in dairy cows based on the response of ruminal $\mathrm{pH}$ and milk fat production to composition of the diet. J. Dairy Sci. 91, 2046-2066. 